\title{
The Electrochemical Monitoring of the Perturbation of Charge Transfer through DNA by Cisplatin
}

\author{
Elicia L.S. Wong", J. Justin Gooding* \\ School of Chemistry, The University of New South Wales, Sydney, 2052 AUSTRALIA
}

\section{Electrochemical Quantitation of DNA Probes}

The surface-immobilized DNA was calculated from the number of cationic redox molecules, rutheniumhexaammine $\left(\mathrm{Ru}\left(\mathrm{NH}_{3}\right)^{3+}\right)$, that were electrostatically associated with the anionic DNA backbone by providing charge compensation to the DNA backbone. The electrochemical quantitation of the amount of DNA immobilized on the electrode was performed using the chronocoulometry procedure as outlined previously by Steel et $_{\text {al }}{ }^{13}$

In a typical experiment, the chronocoulometry plots (charge $v s$. square root of time) of the DNA recognition surface

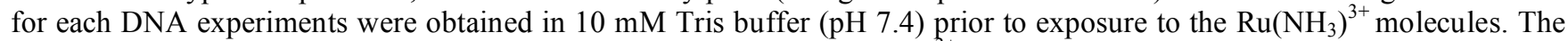
DNA interface was then allowed to equilibrate in $50 \mu \mathrm{M} \mathrm{Ru}\left(\mathrm{NH}_{3}\right)^{3+}$ solution for $30 \mathrm{~s}$ with stirring followed by chronocoulometry measurements in the same $\mathrm{Ru}\left(\mathrm{NH}_{3}\right)^{3+}$ solution. The surface coverage of the redox marker was calculated as the difference in the chronocoulometric intercepts in the absence and presence of redox marker.

\section{Electrochemical Detection of DNA Hybridization and Single-base pair Mismatched via Long-Range Charge Transfer Chemistry}

The electrochemical detection of DNA hybridization using the long-range charge transfer approach was as described previously. ${ }^{9}$ Briefly, the thiolated probe single stranded DNA (ssDNA) was immobilized onto the gold working electrodes via gold-sulphur self-assembly chemistry. The DNA modified surface was subsequently immersed in a solution of diluent layer of 6-mercaptohexanol $(\mathrm{MCH})$ to cover any bare gold to minimize any non-specific adsorption of redox intercalator to the electrode surface. The electrochemical transduction of DNA hybridization was carried out by exposing the DNA recognition interface to the electrochemical measuring solution $\left(0.05 \mathrm{M} \mathrm{K}_{2} \mathrm{HPO}_{4} / \mathrm{KH}_{2} \mathrm{PO}_{4}, 1.0 \mathrm{M} \mathrm{NaCl}, \mathrm{pH} 7.0\right)$ containing target DNA (typically $4 \mu \mathrm{M}$ for most experiments unless stated otherwise) and $25 \mu \mathrm{M}$ intercalator (2anthraquinonemonosulphonic acid (AQMS)). High salt concentration is used to screen off the anionic backbone of the DNA to obtain maximum hybridization. Osteryoung square voltammetry (OSWV) measurements were performed at frequent time intervals after exposure of the DNA modified electrodes to allow hybridization to be monitored in real-time (see Scheme 1s). The formation of DNA duplex is characterized by the appearance of shoulder peak at $-400 \mathrm{mV} \mathrm{vs} . \mathrm{Ag} / \mathrm{AgCl}$ in the OSW voltammogram (see Figure 1s (a)). A significant decrease in OSWV currents were observed in the dsDNA containing a single base-pair mismatch (G:A and C:A) in comparison to the perfectly matched DNA duplex. As the mismatch occurs in the middle of the base sequence, the ability of AQMS in solution to differentiate C:A and G:A mismatches suggested that this molecule intercalate above the middle of the DNA duplexes. We believe this phenomenon is due to the electrostatic repulsion between the anionic AQMS molecules and the forest of negatively charged DNA trees projecting from the surface such that the AQMS does not penetrate between densely packed DNA tress to the proximal end of the DNA.

Table 1s. DNA sequence for each DNA modified surface.

\begin{tabular}{|c|c|}
\hline $\begin{array}{l}\text { DNA Modified } \\
\text { Surface }\end{array}$ & DNA Sequence \\
\hline P1 & $\begin{array}{l}\left.\text { 5'-GGGGCAGTGCCTCACAACCT-p-( } \mathrm{CH}_{2}\right)_{6}-\mathrm{SH}-3^{\prime} \\
\text { 3'-CCCCGTCACGGAGTGTTGGA-5' }\end{array}$ \\
\hline P2 & $\begin{array}{l}\text { 5'-GGAAAAAAAAAAAAAAAAAA- } p-\left(\mathrm{CH}_{2}\right)_{6}-\mathrm{SH}-3^{\prime} \\
\text { 3'-CCTTTTTTTTTTTTTTTTTTT-5' }\end{array}$ \\
\hline P3 & $\begin{array}{l}\text { 5'-AAAAAAAAAAGGAAAAAAAA - } p \text { - }\left(\mathrm{CH}_{2}\right)_{6}-\mathrm{SH}-3 \text { ' } \\
\text { 3'-TTTTTTTTTTCCTTTTTTTT-5' }\end{array}$ \\
\hline P4 & $\begin{array}{l}\text { 5'-AAAAAAAAAAAAAAAAAAGG - } p-\left(\mathrm{CH}_{2}\right)_{6}-\mathrm{SH}-3^{\prime} \\
\text { 3'-TTTTTTTTTTTTTTTTTTCC-5' }\end{array}$ \\
\hline
\end{tabular}

Scheme 1s. Electrochemical detection of DNA hybridization via the long-range transfer approach.

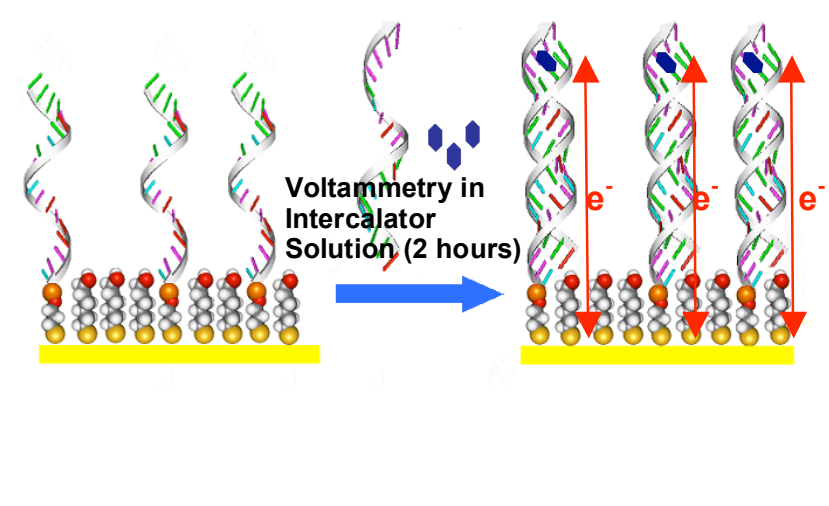

\footnotetext{
\# Current Address: Physical and Theoretical Chemistry Laboratory, University of Oxford, South Parks Road, Oxford OX1 3QZ, UK
} 


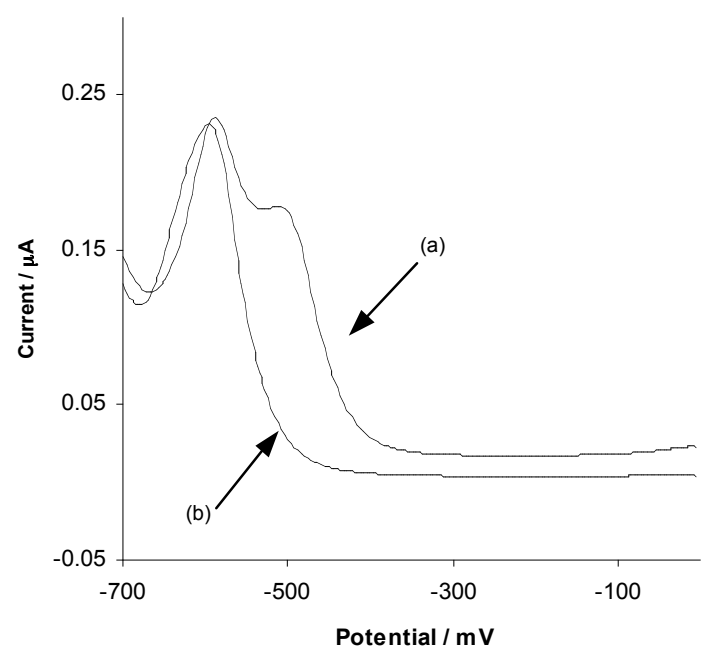

Figure 1s. The electrochemical experiments were conducted in the electrochemical solution consisting of 25 $\mu \mathrm{M}$ AQMS, $0.05 \mathrm{M}$ phosphate buffer ( $\mathrm{pH} 7.0$ ), $1.0 \mathrm{M} \mathrm{NaCl}$, by exposing the ssDNA modified electrode to (a) $4 \mu \mathrm{M}$ of complementary target ssDNA and (b) $4 \mu \mathrm{M}$ of non-complementary target ss-DNA. The occurrence of shoulder peak is only observed when the probe DNA is exposed to complementary target DNA but not to noncomplementary target. This provides strong evidence that the appearance of shoulder peak is due to long-range charge transfer from the redox intercalator to the gold surface via the formation of double-stranded DNA (dsDNA) at the gold surface. In all the OSWV measurement, the step is $4 \mathrm{mV}$, with pulse amplitude of $25 \mathrm{mV}$ and frequency of $10 \mathrm{~Hz}$.

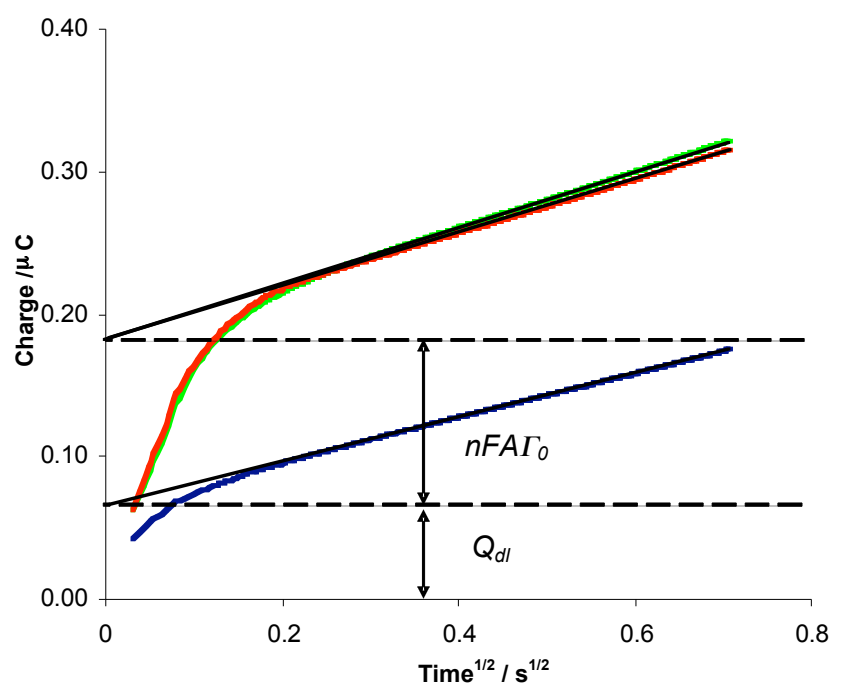

Figure 2s. Chronocoulometric response curves of the dsDNA modified surface in the absence (blue) and presence (red) of $\mathrm{Ru}\left(\mathrm{NH}_{3}\right)^{3+}$ before exposure to cisplatin. The surface coverage of $\mathrm{Ru}\left(\mathrm{NH}_{3}\right)^{3+}$ was calculated as the difference in the chronocoulometric intercepts in the absence and presence of $\mathrm{Ru}\left(\mathrm{NH}_{3}\right)^{3+}$. The surface coverage of $\mathrm{Ru}\left(\mathrm{NH}_{3}\right)^{3+}$ is then converted to DNA surface density with the relationship $\Gamma_{D N A}=\Gamma_{0}(z / m)$, where $\Gamma_{D N A}=$ surface density of DNA, $\Gamma_{0}=$ surface coverage of $\mathrm{Ru}\left(\mathrm{NH}_{3}\right)^{3+}, z=$ charge of the $\mathrm{Ru}\left(\mathrm{NH}_{3}\right)^{3+}$ and $m=$ the number of bases of DNA. The green plot is the chronocoulometric response curve obtained in the presence of $\mathrm{Ru}\left(\mathrm{NH}_{3}\right)^{3+}$ using the same dsDNA modified surface after exposure to cisplatin. The identical chronocoulometric intercepts obtained before (red) and after (green) exposure to cisplatin in the presence of $\mathrm{Ru}\left(\mathrm{NH}_{3}\right)^{3+}$ suggested that there is no change in the amount of DNA on the electrode surface. 